\title{
时部管症候群の手術成績
}

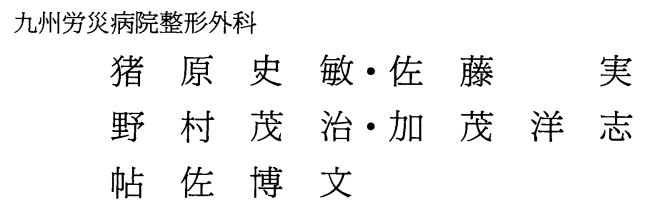

\section{Clinical Results following Surgical Treatment for Cubital Tunnel Syndrome} by

\author{
Fumitoshi Ihara, Minoru Sato, Sigeharu Nomura, \\ Yoshi Kamo and Hirofumi Chosa \\ Department of Orthopaedic Surgery, Kyushu Rosai Hospital
}

\begin{abstract}
In general for cases of osteoarthritis of the elbow with cubital tunnel syndrome we perform anterior transposition of the ulnar nerve for cubital valgus and the modified King's procedure, that is medial epicondylectomy with neurolysis of the ulnar nerve.

From 1984 to 1993, 57 elbows with cubital tunnel syndrome were treated by modified King's procedure in 45 elbows, by submuscular transposition of the ulnar nerve in 7 elbows and by subcutaneus transposition of the ulnar nerve in 5 elbows. The duration of follow-up was 1 to 9.7 years (mean 4.7 years) after surgery. Results were as follows : excellent, 15 ; good, 32 ; fair, 6 ; poor, 4 according to Akahori's criteria. The results depended on the severity. That is, all cases of stage I and II according to Akahori's classification had excellent or good results, but did not depend on duration of their symptoms. As regard to anterior transposition of the ulnar nerve, both submuscular and subcutaneous transposition achieved good results and there is not a difference between submuscular and subcutaneous transposition. The factors of fair and poor results were combined into cervical spondylotic myelopathy and insufficiency of bone resection and stage IV in Akahori's classification.
\end{abstract}

Key words : Cubital tunnel syndrome (肘部管症候群), Clinical results (臨床成績), Modified King's procedure (キング変法), Anterior transposition of the ulnar nerve (尺骨神経前方移行)

\section{はじめに}

肘部管症候群は日常しばしば遭遇する疾患である。 徐々にではあるが進行性であり早期に適切な治療を行 えば予後は比較的良好といわれている。しかし高度の 筋萎縮を伴うと予後が不良になることが多い.我々は 進行する知覚障害, 筋萎縮の出現に加え, 时部での神 経伝導速度の遅延を確認し手術適応とし, 外反时 (-) の時は King 変法（内上顆切除十神経刋離）を，外反
时（+）の時は筋層下ないし皮下前方移行を行ってき た. 今回, その治療成績に文献的考察を加え検討した ので報告する。

\section{対象及び方法}

過去 10 年間に肘部管症候群と診断し手術を施行, 1 年以上経過した 78 例 83 时のうち追跡可能であった 55 例 57 时を対象とした. 男性 47 例, 女性 8 例, 年 齢は 26 才から 79 才 (平均 53.0 才), 経過観察期間は 
表 1

術後成績

(赤堀の評価基準による)

罹病期間と治療成績

\begin{tabular}{|c|c|c|c|c|c|c|c|c|c|c|}
\hline & I & II & III & IV & & $\sim 3(\mathrm{M})$ & $\sim 6$ & $\sim 1(\mathrm{Y})$ & $\sim 2$ & $2 \sim$ \\
\hline 優 & & 8 & 6 & 1 & 優 & 4 & 7 & 2 & & 2 \\
\hline 良 & & 20 & 12 & & 良 & 10 & 11 & 8 & 3 & 1 \\
\hline 可 & & & 4 & 2 & 可 & 1 & & 1 & 2 & 2 \\
\hline 不可 & & & 3 & 1 & 不可 & & 2 & 2 & & \\
\hline
\end{tabular}

表 2

\begin{tabular}{|c|c|c|c|c|}
\hline & 術前 & 㐫期 & 術後 & 成績 \\
\hline \multirow{3}{*}{ 筋層下 } & II & 3 & 優 & 2 \\
\hline & III & 3 & 良 & 4 \\
\hline & IV & 1 & 可 & 1 \\
\hline \multirow{3}{*}{ 皮下 } & II & & 優 & 2 \\
\hline & III & 2 & 良 & 3 \\
\hline & IV & 1 & & \\
\hline
\end{tabular}

表 3

筋萎縮の罹病期間と筋回復

\begin{tabular}{l|c|c|c|c|c|c}
\hline \hline & $\sim 3(\mathrm{M})$ & $\sim 6$ & $\sim 1(\mathrm{Y})$ & $\sim 2$ & $2 \sim$ & 計 \\
\hline 回復 $(+)$ & 4 & 2 & 2 & 1 & & 9 \\
\hline 回復 $(-)$ & 3 & 4 & 8 & 2 & 3 & 20 \\
\hline
\end{tabular}

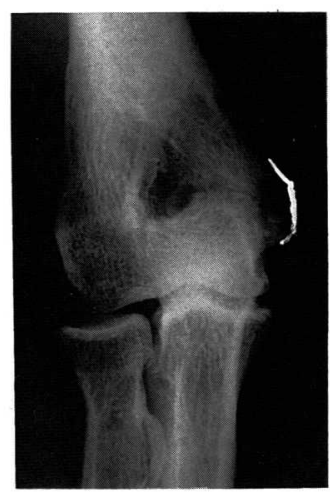

術前

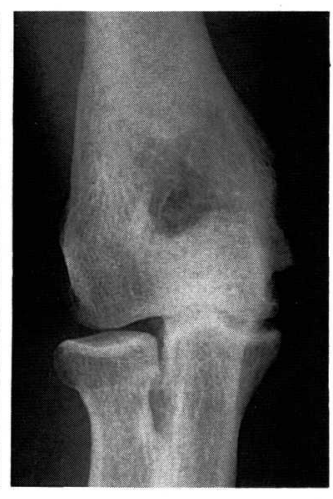

術後
図 1

1 年前よりしびれ感あり 半年前前医で手術するも症状不変 術前 Stage II 術後成績 良
1 年から 9 年 8 か月 (平均 4 年 8 か月) であった. 術 前を赤堀の診断基準 ${ }^{1)}$ でみると, Stage IIが 28 时, stage IIIが 25 时, stage IVが 4 肘で, stage I, V は 0 时であった。手術方法は King 変法 45 时, 筋層下 前方移行 7 时，皮下前方移行 5 时であった。

\section{結果}

1 ）赤堀の評価基準でみると優：15 肘, 良：32 肘, 可： 6 时, 不可： 4 时で概ね良好な成績であった。術 前 Stage II は全て優か良であったが, III，IVとなる と可, 不可が増加し, 可 6 时は Stage IIIが 4 时, IV が 2 时, 不可 6 例は Stage IIIが 3 时, IVが 1 时であっ た.

2 ) 罹病期間と成績の間には殆ど相関関係はなかっ た(表 1 ).

\section{考 察}

\section{A）治療成績について}

罹病期間が短いほど, また Stage が早いほど成績 が良いといわれているが2) 罹病期間と成績の間には差 はなく, Stage 間には成績の差があった（表 1 )。つ まり罹病期間が短いほど成績が良いといわれていたの はそれだけ Stageが進んでいないためで罹病期間は 問題ではなくその時点での Stageのみが成績に影響 をあたえるということである。

B）治療方法について

King 変法と前方移行法を比較する. 我々は时部管 症候群において外反时（+）には前方移行を, 外反时 （一）には King 変法を行ってきた. King 変法は優： 12 肘, 良: 24 肘, 可： 5 肘, 不可： 4 时で移行法は 優： 3 时, 良： 8 时, 可： 1 时と両群間に差はみられ ず良好な成績であった。 つまりこの適応に問題がなかっ たといえる。

C) 前方移行の方法（表 2) 
これまで多くの報告があり，それぞれの利点，欠点 が言われている. 生田ら (1977) ${ }^{3)}$ は皮下移行は外部 からの刺激を受けやすい, 立花ら $(1981)^{2)}$ は移行し た神経が内側へ滑落し再手術が多いという理由で筋層 下移行を推奨し, Stuffer (1991) ${ }^{4)}$ は術後 10 年の成 績で皮下移行が優っていた。佐藤ら (1993) ${ }^{5)}$ は筋層 下移行は手技が煩雑で熟練を要し, 筋力低下や筋層下 での再絞扼も否めないので皮下移行を推奨している. 我々の症例は筋層下 7 时, 皮下 5 时と症例数は少ない が両群間に差はみられず佐藤らが言うように皮下脂肪 の極端に少ない例は筋層下が好ましいと思われるが神 経の滑脱を防ぐ工夫をし， atraumatic に丁寧に行え ばどちらの手術方法でも問題ないと思われる。

D) 知賞障害の回復

一般的に知覚障害が軽いときは術直後から回復する のが多いが少し重症になると術直後の回復は悪く半年 $\sim 1$ 年後にプラトーに達するのが多い6). しかし Stage 間では回復の時期に差はみられなかった。

E) 筋萎縮の回復 (表 3 )

はっきりした筋萎縮としてとらえられるIII，IV型の 29 肘でみると実際に回復したのは 9 时 (31\%) しか なく, 回復までの期間は早くても半年, 多くは 1 年以 上 2 年近くかかっていた ${ }^{6)}$. 筋萎縮が出現してから手 術までの期間でみると半年以内は 13 肘中 6 时 (46\%) に回復がみられたがそれ以上になると 16 时中 3 时 （19\%）しか回復していないので筋萎縮が出現したら 早期に手術したほうが回復の可能性が高い。なお Stage 間（III，IV）には回復度に差はなかった。

F）成績不良因子の検討

成績不良例（可： 6 时，不可：4 肘）を検討すると 3 时は頸䯣症で同時に頝椎の手術を受けており， 2 时 は頸髄症，OPLL を合併して保存療法中で，1 时は 以前頸髄不全損傷で前方固定を受けていていずれも Double lesionによる尺骨神経の易損性がうかがわれ， 病変責任病巣の同定，術後評価の難しさなどが問題と なると思われた。 2 时は術後レントゲンで明らかに骨 切除不足があり再手術で十分切除を行った結果, 症状 軽減し, 成績は良となり改善した。残り 2 时は術前診 断が Stage IVで従来の報告のように早期の手術の必 要性が感じられた。

G）手術のタイミング
以上より Stage IIからIIIに移行する前，即ちはっ きりした筋萎縮が出現したらすぐに手術を行ったほう が良い。

\section{症 例 供 覧}

36 才, 男性. 1 年前より右前腕尺側から小指にか けてしびれ感があった。半年前前医で手術を受けるも 症状が全く不変のため当科受診した。尺骨神経領域の 知覚障害があり第一背側骨間筋に筋萎縮はないものの 示指外転の筋力低下を認めた。筋電図学的にも肘部管 症候群であり赤堀の診断基準では Stage II であった。 レントゲンで骨切除不足が存在していたので再手術を 行った。術中尺骨神経は内上顆部で絞扼があり肘の屈 伸でも尺骨神経はスムーズに滑動しなかった。十分な 骨切除とステロイドによる Internal neurolysis を行 い，屈伸による滑動性が良好になったことを確認して 創閉鎖した。術後知覚障害は消失し成績は良であった。

\section{ま と め}

1. 肘部管症候群の 57 肘の治療成績を検討した。

2. 赤堀の Stage II はすべて優か良であったが Stage III，IVになると可，不可がみられるようになり 早期の手術の必要性がある。

3 ．前方移行は皮下移行と筋層下移行の間に差はな くどちらも良好な成績が得られた。

4. 成績不良例を検討すると 6 时に頝椎との Double lesion を窺わせ， 2 时は骨切除不足があり， 2 时は術前診断が Stage IV であった。

\section{参 考 文 献}

1）赤堀 治他：遅発性尺骨神経麻痺の早期診断と治療， 整形外科, $23: 94-102,1972$.

2）立花新太郎他：时部管症候群一尺骨神経前方移行術の 予後について一整形外科, $32: 1590-1593,1981$.

3）生田義和他：肘部管症候群に対する手術的治療，災害 医学, 20:447-454, 1977 .

4) M. Stuffer et al. : Subcutaneus or submuscular anterior transposition of the ulnar nerve?, J. Hand Surgery, 17B : 248-250, 1991.

5）佐藤勤也：肘部管症候群に対する手術術式選択のポイ ント，整形外科 MOOK 増刊， 2-D：96-99，1993.

6）今井克己他：时部管症候群の術後長期経過例に打ける 症状回復過程について, 日手会誌, 2 : 201-204, 1985. 